This is the version of the article accepted for publication in Interventions: International Journal of Postcolonial Studies published by Taylor \& Francis: https://www.tandfonline.com/doi/abs/10.1080/13698019800510211 Accepted version downloaded from SOAS Research Online: http://eprints.soas.ac.uk/30344

\title{
Present Absence: Book circulation, Indian vernaculars and world literature in the nineteenth century
}

submitted to special issue on "The Vernacular in World Literature" edited by Stefan Helgesson for Interventions: Internationa Journal of Postcolonial Studies (May 2018).

\section{Francesca Orsini}

Department of Languages, Cultures, and Linguistics, SOAS, University of London Thornhaugh Street, Russell Square, London WC1X9PF

Telephone: 02078984242 email: $\underline{\text { fo@soas.ac.uk }}$

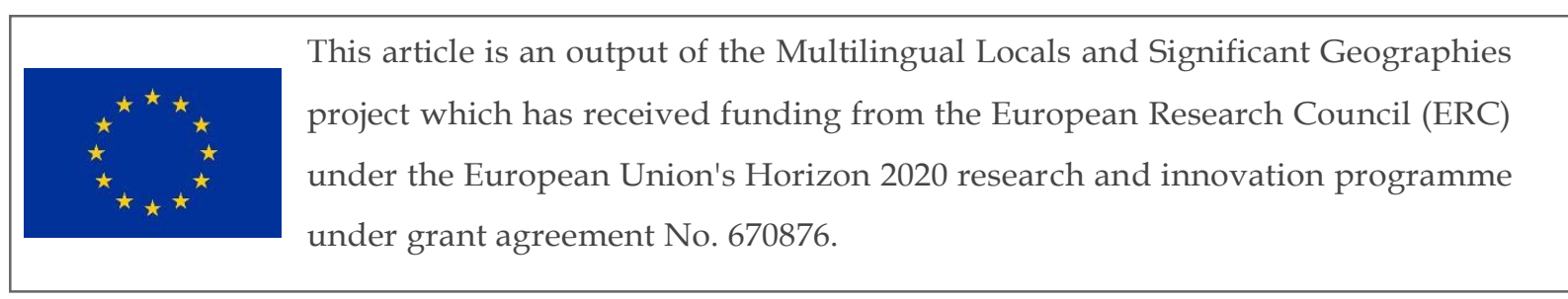

\begin{abstract}
:
More books from India in Indian languages circulated in Europe in the nineteenth century than now--partly thanks to the efforts of book importers like Trübner \& Co. Trübner's monthly American and Oriental Literary Record (1865-) shows pages and pages of imported Sanskrit books, but also Hindi, Hindustani, Bengali, Marathi, Telugu, Gujarati, Arabic, Persian, and so on. Trübner also imported Peruvian, Argentinian, Brazilian, Yucatanese and other books from Latin America. Yet this impressive circulation and presence of books did not translate into their recognition as world literature. Voluminous compendia like John Macy's The Story of World Literature (1927) cover "Asian Literature" in merely 13 pages (out of 500), and fail to mention any modern Indian writer apart from Rabindranath Tagore, damning him with faint praise. Why was this material presence and circulation of books in nonEuropean languages in Britain and other parts of Europe matched by their absence as modern literary texts from the imagination of world literature? This essay
\end{abstract}


examines the "technologies of recognition" (Shih) that made modern Indian literatures virtually invisible though materially present in Europe, and the conditions of visibility that occasionally allowed them to be seen.

Present Absence: Book circulation, Indian vernaculars and world literature in the nineteenth century

This essay stems from a discovery and a frustration. The discovery was of the monthly American $\mathcal{E}$ Oriental Literary Record that the German-British book importer and publisher Nicholas Trübner (1817-1884) launched in London in 1865. (If you work with books published in India in the British Library, you are likely to have encountered the Trübner tag.) The number and range of books that Trübner imported from Latin and North America, from India, China, and later Africa and the Middle East, in English but also in the local languages is truly amazing. (Fig. 1) INSERT FIG. 1

A staggering number of books in Sanskrit, Hindi, Urdu/Hindustani, Marathi, Gujarati, Telugu, Tamil, etc. reached Paternoster Street in London every month-even in the age of Amazon, this has just no equivalent today. Very much the product of this earlier global moment enabled by developments in transcontinental transport and travel and the boom in the comparative study of world language(s), this flow of books on an unprecedented scale seemed to turn the idea of world literature into a reality. This is also the language that Trübner spoke in the first issue (Fig. 2).

INSERT FIG. 2

We desire to bring the literature of the East and West more fully before the reading public of England and Europe, with this in view we propose presenting to our readers a monthly record of every important work published in North and South America, in India, China and throughout the East. We are not aware of any previous systematic attempt of this kind, but we think the time is ripe for such an undertaking, and unhesitatingly ask the support of all students and lovers of literature, believing that when our object is fully understood we shall neither lack 
readers nor sympathisers" (American \& Oriental Literary Record 1, 1865, 1, emphasis added)

East and West, uniquely systematic and timely--the ambition and optimism of this declaration are palpable, while its definition of literature is ambiguous, as was typical in this period. "Lovers of literature" suggests belles lettres, while "every important work published" indicates literature as "useful knowledge". The intended audience are named as "students and lovers of literature", but elsewhere it's scholars and libraries in England and Europe. And while American and Asian literature, as "literature of the East and West", seem to flank the European centre, still the presence of so many books in languages other than European ones is thrilling.

So this is the thrilling discovery. The frustration comes from asking why (and how) did this physical presence of so many books translate into a pretty much complete absence of modern Indian literature and writers--my particular interest--from the imagination of Indian and world literature at the time. In book after book on Indian literature and series after series of world literature, whether in German, English or Italian, Indian literature simply meant Sanskrit, or at a stretch Sanskrit and Pali, literature. So in Paul Wiegler's 1932 Geschichte der Weltiliteratur, the chapter on "die Inder" included only Brahminical Literature, the epics (Mahabharata, Ramayana, Kalidasa), drama, and Buddhist literature (page), and the same was true of Hanns von Eppelsheimer 1937 Handbuch der Weltliteratur. In John Macy's 1927 The Story of World Literature, the only exception was Tagore, but even there the paternalistic tone of superiror indifference is unmistakable. In his brief chapter (13 pp. out of 500) entitled "The Mysterious East-Chinese-Japanese-Indian-Arabic", which came right at the beginning after "The Beginnings of Literature", he wrote:

In our own days an Indian poet has arisen whose voice is heard beyond the intellectual frontiers of his faith and language. This is the Bengali Rabindranath Tagore. Something of the bloom and cadence of his verse must inevitably be lost in translation. We are told that he has a delicate sensitive ear for the music of words... (Macy 1927, 43) 
Given that this was the time of the great Urdu poet Ghalib (d. 1869), of so many seminal Bengali authors like Michael Madhusudan Dutt (1824-1873) and Bankimchandra (1838-1894), of Bharatendu Harishchandra in Hindi (1850-1885) and Dalpatram (1820-1898) and Narmad (1833-1886) in Gujarati, to name but a few, nothing of this flourishing modern literature in Indian languages transpires in these books, or even in Trübner's American E Oriental Literary Record. Even when a few works by modern Indian authors were translated, as we shall see, they do not seem to have changed the general perception of the absence of modern Indian literature. They were not read as literature (Damrosch 2003).

Shu-Mei Shih has talked of the "technologies of recognition" that come into play when the publishing market and literary scholarship engage with non-Western literature, technologies which "produce 'the West' as the agent of recognition and 'the rest' as its object" $(2004,17)$. And Aamir Mufti has argued that it was Orientalism which provided the conditions for world literature to be imagined in the first place. From William Jones onwards, Mufti writes, “Orientalism may be understood as a set of processes for the reorganization of language, literature, and culture on a planetary scale, which effected the assimilation of heterogeneous and dispersed bodies of writing onto the plane of equivalence and evaluability that is literature" (2010, 488). But, as often (always?) in varieties of one-world thinking, what is presented as complete--in this case assimilation in the category of literature (Trübner's "literature of East and West" in a "systematic fashion", see above)--is in fact significantly incomplete, only very partial. It excludes while it claims to include. What is excluded then becomes invisible and ceases to exist--at least in the eyes of the viewer. In this essay, then, my concern is with the "technologies" that produced blindness and ignorance of, or disregard for, modern Indian literature in the second half of the nineteenth century even when other evidence, from the books Trübner imported to the teaching of modern Indian languages and, importantly, to the counter-example of the French Orientalist Garcin de Tassy, suggests that the conditions to see were there. So why, and how, was modern Indian literature made invisible? 
In this essay I go though what Trübner imported, how the American E Oriental Literary Record talked about Indian literature and where it got his information from, what works of modern Indian literature Trübners and others published and translated, and the discourse around translation in the paratexts to these works. I contrast them with the contemporary discourse and translations of the French scholar Garcin de Tassy, before ending with a list of reasons why and how modern Indian literature was invisibilized in this traffic. Since almost all the texts that were translated into English were originally produced or printed at Fort William College under John B. Gilchrist (1759-1841), it is useful to first revisit them in the light of our questions.

\section{Fort William College, Hindustani, and Urdu literature}

Gilchrist and Fort William College at Calcutta (particularly under his short tenure as Professor of Hindustani there, between 1800 and 1803) are usually remembered in Hindi and Urdu scholarship for two things--Gilchrist's sponsorship of prose texts written by the modern language teachers at the College that marked the beginnings of modern Hindi and Urdu literatures, and his momentous definition of language. Gilchrist called the modern language of North India Hindustani (Hindostanee), divided it into three levels, and distinguished between the "Middle or Genuine Hindostanee Style" in Persian script (what soon came to be called Urdu) and rustic Hindi (Hinduwee) in Nagari script as the language of Hindus alone (Safadi 2001, 10, Steadman Jones 2007). This definition is usually read as part and parcel of a colonial policy of divide et impera aimed at creating a split between Hindus and Muslims (e.g. Faruqi 2001). It was certainly part of an ethnographic vision that saw Hindus and Muslims as separate groups and that linked script, language, cultural tradition and religious community into a single cluster. Here, however, I want to focus on another aspect, namely that despite these two undisputed points in practice Fort William College publications, which were among the first printed versions of modern Indian 
literature and circulated widely in Europe (Fig. 3), did other things, too (see also Orsini forthcoming).

FIG. 3 here

First, despite the language division and separation, several of the texts produced at Fort William College--like the stories of Mirza Kazim 'Ali Javan's Singhasan battisi (1803) or Haider Bakhsh's Tota kahani (1804)--were printed in both Urdu and Nagari scripts with hardly any lexical changes, implying that they were in fact mutually intelligible in terms of language, characters, and stories (see Pritchett n.d.). We can visualise these texts as an area of overlap, with texts printed in only one script as outliers. Second, Gilchrist is usually remembered as the Orientalist who fought the Hindustani/modern vernacular corner against those other Orientalists who insisted on teaching East India Company recruits Sanskrit, Persian or Arabic, but we can also see him as making the case for Hindi-Urdu (to use the later denominations) as the current language of North India and as recognizing and appreciating the Persianate, Urdu literary tradition. By contrast, the professor of Bengali insisted that all students taking Bengali should also study Sanskrit, appointed only Brahmin pandits as Bengali teachers, and would not accept any who knew some English as well because it "corrupted" their language (Das 1978, 65).

Moreover, the books that Gilchrist had printed at the College or other presses in Calcutta included what we now consider modern Urdu classics, works written only fifty years earlier, like Miskin's elegies (marsiye, 1801, also printed in Nagari script ), Mir Hasan's narrative poem Siḥr ul-bayān (320 pp., 1802/3?), and later the diwan of Mir Soz (1810), selected satirical masnavis by Sauda (Intikhabi Suoda, 1810), and the complete works of Mir Taqi Mir (Koolliyati Meer Tyqee, 1811). In other words, Fort William College sponsored the publishing of some of the best-known eighteenthcentury Urdu poets from Delhi and Lucknow, who each had done something new with language and with different Persianate genres. In this respect, Gilchrist made the broader spectrum of modern Urdu literature available in print.

To press the point about temporality, we tend to think of late-Mughal Delhi and Nawabi Lucknow as "pre-modern" and colonial Calcutta as "modern" --i.e. we do 
not think of them as coeval--but in fact Fort William College personnel and publications show that they were part of a two-way traffic (see also Hakala 2006). Fort William College prose texts fed back into Lucknow Urdu literary culture, so that for example one of the most famous Urdu poetic works of nineteenth-century Lucknow, Dayashankar Nasim's verse narrative Gulzār-e nasìm (The Garden of Nasim, 1838) directly acknowledged the prose version written by Nihalchand Lahori for Fort William College (Gul-e bakawali, The Bakawali Flower, 1804) as its source (Suvorova 2000). Equally, what is usually foregrounded in the case of Fort William College is the novelty of prose, which in fact became a metonym for the modern age, so that in literary histories the nineteenth century is often simply called "the age of prose". But if again we look more closely at some of these prose works, we see that they are not very different from verse narratives, and Nihalchand's extremely popular Gul-e bakāwali is half in verse. The distinction between verse and prose becomes rather more blurred.

\section{English translations}

Several of the texts written at Fort William College--Alison Safadi has shown in her work on the teaching of Hindustani (2010)--continued to be part of the syllabus for Hindustani examinations for civilians and in the Indian Army throughout the nineteenth and the first half of the twentieth centuries, even when language instruction supposedly moved from "classical" (i.e. based on translating literary texts) to more pragmatic, and despite repeated attempts to replace them with something new. Safadi (2010) shows that the emphasis in the discourse around the education of EIC officials and in the paratexts of grammars and textbooks went from a "diplomatic" one--where the linguistic ideal was for EIC officers to be able to hold their own with Indian notables, and their inability made them the butt of satire--to an expectation that Indian subordinates should learn English and British officials, barring a few interpreters, only be able to communicate in the simplest terms. This shift in emphasis towards pragmatic communication lessened the need to appreciate rhetoric and etiquette and sharpened the learners' frustration at what they perceived as "bookish" and useless exam textbooks--"that beastly Bagh-o Bahar" went the curse 
of one candidate aimed at that FWC "perennial”, Mir Amman's Garden of Spring (1804, many editions, quoted in Safadi 2001, 104-122).

It was in the context of language pedagogy (or rather, passing the qualifying or interpreters' exams) that English translations of FWC texts by former Indian Army officers or civilians like Major Court, Duncan Forbes, and Matthew Kempson were repeatedly published in India and Britain throughout the nineteenth century. In their prefaces, the translators emphasised the usefulness of these texts for giving "an English student a thorough insight into Eastern customs, modes of speech, and etiquette" (Court 1889, n.p., see Fig. 4).

Fig. 4 here

Of course, the use of literary texts or extracts for language pedagogy was and remains a common practice, but in the case of these Hindi and Urdu texts the label of "textbook" seems to have blocked the possibility that they might be recognized and appreciated also as literature, and as modern literature at that. Instead, British attitudes ranged from paternalism at best to explicit disregard, as we shall see. In Court's case, the translator's effort to present the FWC prose version of Mir Hasan's masnavi Siḥr ul-bayān or, translating the title, "The incomparable prose of Mir Hasan" as "an excellent specimen of an Eastern novel" where "The various ceremonies, in usage at Oriental Courts, are most fully described..." (1889, n.p.), shows where the catch lay. Paradoxically, while the novelty of prose was taken as a sign of the paucity of literature in the Urdu language, at the same time works were either praised or condemned for being "Eastern" or "Oriental”, i.e. not modern enough, caught in the ahistorical chronotope of Oriental courts and adventures. (Yet useful for learning etiquette, perhaps to converse with the celestial paris?)

This instrumental attitude extended to translations that were not part of the pedagogical enterprise, like that Bankimchandra's Kapalakundala, one of the most importan modern Indian novels, by A.H. Phillips of the Bengal Civil Service, a translation Trübner itself published in 1885 (Trübner had died in 1884). In his Introduction, Phillips began by stressing how important it was for all officials, and magistrates in particular, to have "a knowledge of the vernacular". "No doubt, 
speaking generally, the vernacular languages of India are not worth studying for the sake of their literature", he added, "but in this respect, if one vernacular is worth of study more than another, it is certainly the Bengali language" $(1885$, ix-x). Phillips is an example of what I mean by "paternalism at best." "Many people in England regard the natives of India much in the same light as the natives of Africa. A perusal of the following tale will at least give some conception of the stage of civilisation at which the Bengali race has arrived" $(x)$, he stated, before launching into a gazetteerlike survey of the Bengal province, with data on census and migration, population per $\mathrm{m}^{2}$, prospects for agricultural development, the progress of education, judicial administration, land and other revenue, progress in transport and construction industry, wages and other indicators of wealth such as women's jewellery, enduring poverty ("Of course Indians, as compared with Europeans, are poor, and must remain so for a long time to come; but their wants in the shape of food, housing, and clothing, are smaller and more easily satisfied", 1885, xvi), bank deposits, number of post offices, and so on, before he ended by quoting J.R. Seeley's authority that British rule had really brought unity and prosperity to India. As we can see, we are very far from a literary-aesthetic approciate. Phillips does discuss the "progress of Bengali literature" towards the end of the Introduction, but the tone remains paternalistic:

The foregoing sketch is of use in judging and accounting for the peculiar position and character of Bengali literature. A backward people have, so to speak, rushed to civilization at one bound; old customs and prejudices have been displaced, uno iucto, by a state of enlightenment and advanced ideas. The educated classes have suddenly found themselves face to face with the richest gems of western learning and literature. The clash of widely divergent stages of civilization, the juxtaposition of the most advanced thought with comparative barbarism has produced results which, though perhaps to be expected, are somewhat curious. [I.e. Bengalis have been trying too much too quickly] If one tries to close a box packed with more than it can hold, the lid may be unhinged, - new wine may burst old bottles. The colliding forces of divergent stages of civilization have produced a literature that, for want of a 
better expression, may be called a hybrid compromise between eastern and western ideas." (1885, xxi-xxii)

This is before hybridity became a good thing. The reason I quoted this passage at length is because some of the tropes used--of the novel as a "hothouse plant from foreign soil" (though "better than the farragos of original nonsense")--have been enduring ones in discussions of early Indian novels. And because even this translation of a modern novel that was not aimed directly at passing language exams was still framed in terms of language learning and insight into a region or a people's etiquette and invited an instrumental reading, not a literary one, or a scholarly reading as was the case with Sanskrit books.

A corollary to this attitude was the belief that any modern development in Indian vernacular literatures could only come from following Western models. Hence the emphasis on translations from English as the chief means of literary innovation, a belief that many Indian intellectuals came to share. As a matter of fact, in many Indian languages innovation of genres, themes, and diction took place largely through translations across Indian languages, in the case of Hindi from Bengali, Urdu, or Marathi (McGregor 1972, Mukherjee 1985). And arguably Urdu poetry in the eighteenth century had already been innovative in terms of language register and theme in so many ways (Suvorova 2001, Vanita 2012, Knapczyk 2014).

\section{Back to Trübner}

Let us now return to Trübner and his monthly American \& Oriental Literary Record. How many, among the many books in Indian languages that he imported, were of modern literature? And how attentive was the Record to them in the short notes called Oriental Literary Intelligence that came with the lists?

The first thing to say--which takes us back to the point about the misleading perception that "global" claims often entail--is that his import was not as systematic as it claimed to be. We find in his lists no books from Delhi or Lucknow, both important publishing centres, and no books from the extensive Naval Kishore catalogue (Stark 2007) until 1869, when Trübner's effort at importing books in Indian 
languages was already peaking. The larger point I want to draw out here is that even a project that presented itself in such global and systematic terms relied on a rather fragile network of single individuals for information and to provide the books. Trübner's Notes mention Gottlieb Wilhelm Leitner (1840-1899), the HungarianGerman of Jewish background who became principal of Government College Lahore. Another likely informer and correspondent was James Long, since the notes on vernacular literature quoted from the monthly Calcutta Review that Long edited are among the very few occasions when the new "vernacular literature" is mentioned at all. It was probably thanks to Long that we find the only occasion in which a modern author is singled out, recognized and projected as such (Michael Madhusudan Dutt, Fig. 5), while for example Ghalib or Bharatendu Harishchandra are only mentioned as part of an undifferentiated list (Fig. 6).

Fig. 5 here

Fig. 6 here

Long, whose 1865 Descriptive Catalogue of Vernacular Books and Pamphlets had been part of the display of the Government of India at the Paris Exposition in that year, returned to London in 1872, and this seems to have marked the end of notices on Bengali poets. And apart from the works of the French Orientalist Garcin de Tassy himself and the other textbook translations mentioned so far, Trübner seems to have published (or reissued) few if any books on Hindi and Urdu literature. The anthology Nuskha-i Dilkusha is advertised in 1874, but appears only once. We must keep this all in mind for when we return to Garcin de Tassy at the end.

Fig. 7 here

By comparison, Sanskrit books and Sanskrit news dominated the section called Oriental Literary Intelligence in Trübner's Record (Fig. 7). Trübner himself had studied Sanskrit at King's College London, and the Record is profuse in information about the transcontinental network of classical Orientalists, their forthcoming publications, the international congresses, and so on. On the occasion of the second one in London in 1874, Trübner came out with a special issue with the speeches and proceedings. The balance between classical and modern Indian languages was therefore heavily schewed towards the former. 
As I suggested in passing, perhaps Trübner's American $\mathcal{E}$ Oriental Literary Record peaked too early for modern Hindi literature to come into its own and find recognition. Trübner died in 1884 and the widow and partners sold the firm to Kegan, Paul \& Trench in 1889 (Howsam 2014-16), by which time the Record had shrunk to a few pages. The grand scheme of bringing to European readers "literature from the East and West" in their own languages does not seem to have found enough takers, or to have stimulated their translation into European languages. By contrast, a small but steady corpus of Sanskrit poetic works was translated and retranslated across European languages, in popular as well as scholarly editions (Italia 2018).

To check how much of modern Hindi literature was known in European languages, I went back to George A. Grierson's 1889 history of the Modern Vernacular Literature of Hindustan, which grew out of a speech delivered before the International Congress of Orientalists in Vienna in 1886--its original audience was therefore one of largely European Orientalists. To start with, "modern" in the book is to be taken in the Orientalist sense, as post-Prakrit and somewhere in the second half of the first millennium CE. Grierson began boldly and somewhat pugnaciously by stating that, "Apologies for dealing with the Neo-Indian vernaculars are not now so necessary as they would have been twenty years ago", and he asked his readers "to take again one step over the very short gap" separating the latest Prakrit from the earliest Hindi (“Gaudian") literature $(1889, x)$. Grierson's sources were his notes, "collected from innumerable texts bought in the bazārs", and "almost entirely from native sources" (1889, xiii) Chief among them was Shiv Singh Sengar's Śivsiṃh saroj (2nd ed. 1883), which accounts for the centrality and profusion of courtly poets of short poems (kabitt) in the literary vernacular called Brajbhasha despite Grierson's evident dislike of them in principle. Grierson's innovation with respect to Sengar, as others have noted, was historical periodisation and the greater emphasis on devotional bhakti poets, particularly his favourite Kabir and Tulsidas, and for his championing of Malik Muhammad Jayasi, the Sufi poet of the Padmāvat (1540). Despite the title, Grierson explicitly excluded Urdu/Hindustani literature from his survey, but devoted two chapters to the ninteenth, which he termed the "renascence" after the "barren period" of the eighteenth century. These were "Hindūstān under the 
Company [1800-1856]" and "Hindūstān under the Queen [1857-1887]". Despite his closeness to current Hindi literary trends and Hindi literati, whom he often encouraged, Grierson's attitude remains paternalistic and contradictory (Fig. 8). Fig. 8 here

What do I mean by that? Grierson equated modernity with the printing presses and the "art of printing", yet he ignored the modern genres that the printing presses introduced--the essay, the skit, the novel, and so on. Literature, in line with his Indian informer Sengar, remained Brajbhasha poetry, and it is Brajbhasha poets that are mentioned and listed. Even in the case of Bharatendu Harishchandra, who is famous as the "father of modern Hindi", Grierson mentions that he had become very famous by 1880 but praises only his anthology of Braj poets (Sundarī tilaka, 1869, Grierson 1889, 124, see Fig. 8) rather than the prose and dramatic writings for which he's justly celebrated in Hindi literary history, not one of which Grierson discusses. Besides, Grierson was authoritative-paternalistic in stressing that Hindi was born under British tutelage and in positing the "progress of Hindi" as something that is always "about to come". His famous phrase runs: "It was the period of the birth of the Hindī language, invented by the English, and first used as a vehicle of literary prose composition in 1803, under Gilchrist's tuition, by Lallū Jī Lāl, the author of the Prēm Sāgar" (1889, xxii). Hindi drama "gives a hope of achieving considerable excellence in the near future" (1889, xxiii). Finally, when Grierson discussed modern trends he always used generic collective terms rather than mentioning specific individual contributions, and was always less than enthusiastic. So, while he singled out the "wide extension of the art of printing" as a benefit of the post-1857 era, "a period free from internal commotion, and in which every inducement has been offered for the spread and acquisition of knowledge", he deplored the fact that the result has been the "floods of printed works, old and new, good, bad, ad indifferent" from "large Native publishing-houses" $(1889,124)$. “Every scribbler can now see his writing in type or lithographed for a few rupees, and too often he avails himself of the power and the opportunity" (ibid.). So was the spread of print a good thing or not? Grierson could praise Hindi newspapers only be in comparison "with the more disloyal and scurrilous contemporaries which disgrace Bangālī journalism” (ibid.). 
Among the few names Grierson did single out for the more recent period of Hindi literary history ... were once more the Brajbhasha poets and scholars that Sengar proffers him ("for the present not only is the proportion of chaff to grain infinitely greater, but the two are as yet unseparated", ibid.). In order to emphasise the technology of recognition at work here, it is worth stressing what Grierson did not emphasise or even mention: any new genres and any particular work or author. So, despite Grierson's brilliant collecting of oral songs and tales, the wonderful manual of material-linguistic culture that is Bihar Peasant Life (1885), and the indefatigable and self-reflexive work of language documentation culminating in the Linguistic Survey of India, his authoritative dismissal of modern Hindi literature contributed to the invisibilization of modern Hindi literature.

\section{Garcin de Tassy}

Well, it was inevitable, we could say. How could Grierson be outside the episteme of his own time? This is where the wonderfully named Joseph Héliodore Sagesse Virtue Garcin de Tassy (1794-1878) comes into play, whose position is at an angle with those discussed so far. Garcin de Tassy was very much part of European Orientalism but had very different ideas and tastes regarding modern Indian literature. On the one hand, he shared ethno-religious ideas about language and divided Hindustani into a "Hindu branch" and a "Muslim branch" (Garcin de Tassy $1851,1874,6)$. He also vigourously "assimilated" the heterogeneous bodies of Indian writing "onto the plane of equivalence and evaluability that is literature" (Mufti XX)-his translations all bear European genre names: monologue dramatique, elegie, récits historiques et élégiaques, roman fabuleux et moraux, and so on. On the other hand, he championed a literary reading and appreciation of modern Indian literature, singled out authors and works, and criticised British superciliousness and translation politics.

Like William Jones fifty years earlier, Garcin de Tassy had come to Indian languages after studying Arabic and Persian (and Turkish), and unlike the later generation of Indologists he retained an interest in Indian Persianate and Islamicate literary 
traditions. When, in the annual discourses he gave at the beginning of the academic year that were regularly published, from 1850 to 1877 , before his death in 1878, he discussed the language debates raging in India at the time, he always took the side of Hindustani, even calling the movement towards Hindi "retrograde" (1866 Discours, 1874, 325), and defended Indian Muslims against what he felt was colonial discrimination (1855 Discours, 1874, 103). While he definitely translated and wrote more about Urdu than Hindi literary traditions (and used available tazkiras to compile the first, tazkira-like history of Urdu literature as early as 1840), he also translated some Hindi works and was knowledgeable about Hindi literary history. But for our purposes Garcin de Tassy is remarkable, indeed exceptional, for his emphasis on the novelty, progress, literariness, and even coevalness of contemporary Hindustani literature. While he nodded in the direction of the "practical utility" of knowing Hindustani for administrators, travellers, doctors, lawyers, traders, and preachers in the first Discours d'ouverture du cours d'hindustanie, on 3 December 1850, he quickly turned to the "present literary interest": "Hindustani has a contemporary literature that is not unimportant and that, moreover, is of topical interest (offre un intérêt d'actualité) which distinguishes it among oriental literatures" (Garcin de Tassy 1874, 1-2). Commenting on the new publications of the year, he noted,

Among the truly original works, several charming poems on the popular legend of Śakuntala, Layla o Majnun, Kala o Kamrūp, Husn o 'Ishq...; travel writing, histories...; several stories and prose narratives, useful lexicographical works, and poetic production of fashionable poets Mumin, Nasir, Zauq, Nazir, Atash, - writers who currently exercise great influence on contemporary Hindustani literature" (Garcin de Tassy 1874, 3, 4)

The repeated emphasis on contemporaneity is not to be missed. Unlike Grierson and others, he singled out contemporary Hindustani authors by name and acknowledged them as such ("un poët contemporaine"), naming the titles of their 
works or the journals in which they had appeared and occasionally translating a few verses as part of his review. He even gestured towards literary coevalness when he spoke in 1859 of the ("Romantic movement which manifested itself in India and in England and has been retained in France", "mouvement romanisant qui s'est manifesté dans l'Inde et en Angleterre a eu en France son retentissement" (1874, 148).

In every annual Discours, Garcin de Tassy returned to the "veritable literary interest [of Hindustani], and it is particularly on this account that it is study is useful in Europe" (1851 Discours, 1874, 5). He in fact complained that British officers did not appreciate the "fabulous novels" like Bagh-o Bahar or Gul-e Bakawali and considered "these admirable works of Hindustani literature chidlish (puérils) and unable to generate truly noble and generous feelings". He referred to one Englishman who was of the opinion that this literature should be entirely replaced by translations from English. Assimilating these Hindustani "novels" to the broader genre of Oriental tales, Garcin de Tassy continued: "He forgets that some of these works are so interesting and have obtained greater success in Europe than any European work", and went on to mention the Arabian Nights, "le livre le plus amusant qu'on pouisse lire" and which instructs on the best Muslims customs. (Instrumentalism was not totally absent, as we can see.) "True", Garcin de Tassy continued, "it is a somewhat light reading, but the same is true of Gulliver's Travels, which the same officer suggests should be translated into Hindustani" (1855 Discours, 1874, 101). Garcin de Tassy died just before the reformist movement took hold in Urdu poetry (Hali's Musaddas dates from 1879), but while defending the tradition of "fabulous Oriental tales" he seemed appreciative of anything new, as well. He criticised of the British politics of translation, "regretted" the preference for translating English histories to Persian ones, pointed out mistakes in the transliteration of proper names, and roundly accused the British of using translations to "infiltrate (infiltrer) among the natives not just European but Christian ideas"' (1855 Discours, 1874, 104). 
Garcin de Tassy himself never went to India, but received a steady flow of publications, reports, and Indian visitors in Paris and stressed the ease with which one could be acquainted with the latest academic and literary news in Europe by subscribing to Indian journals (1850 Discours, 1874, 3). He boasted that one of his articles had appeared in a Benares journal in 1851 (1855 Discours, 1874, 96).

What I find remarkable is that he used exactly the same publications and reports that British scholar-administrators produced and referred to, even used the same format of the annual review, yet the tone and the attitude could not be more different. There is much that he agreed with (i.e. that it was a shame that so many of the books published were reprints or adaptations), but he was quick to welcome any novelty or any work or author of value on the basis of their literary merit. He was well known to Trübner's readers, too, and his works were the only works of modern Indian literatures published by the Oriental Translation Committee (also printed by Trübner), yet he seems to have been alone in his interests and assessments.

\section{Conclusions}

Why did the presence of so many books in modern Indian languages translate in their absence and inisibility as literature from contemporary accounts and from book series of Indian and world literature, this essay began by asking. In the late nineteenth century the possibilities of transcontinental transport of commodities and people had created the promise of a regular and systematic inflow of books in the languages of the world. It was also at this time that the scholarly comparative study of world languages reached its peak. Yet several factors were stacked against the recognition of modern non-European literature (Indian literature has been my focus today) as literature, modern, and coeval.

I have pointed to six processes or technologies at work in combination with one another. First was the "denial of coevalness", that "persistent and systematic tendency to place the referent(s) ... in a Time other than the present of the producer of [here literary] discourse" (Fabian 1983, 31). In our case, the qualifiers "Eastern" 
and "Oriental" seem to have automatically turned even contemporary works into "not modern" or "not-yet-modern" (see e.g. the "Oriental novel"). The second was the foregrounding of modern Hindi and Urdu texts as materials for language pedagogy, which made them somehow unworthy to be treated as "literature". Modern Hindi and Urdu texts were published and translated in Britain and in India, but they were not read as literature. Third, exercising scholarly authority, European (and American) philologists decried Hindi literature as a recent invention, too recent to have produced anything worthwhile yet. Fourth, implied in discussions of the "development" and "modernity" in Indian literature was the assumption that they could only come from following European models (under "British tutelage"). Fifth, even when modern Indian texts, genres, and authors were discussed, they were mentioned either as a group or in passing, denied the recognition of their individual, singular contribution. The form of the "report" almost invited superficial attention and quick dismissal--though as we have seen Garcin de Tassy could turn the very same form into a revue, an appreciation of the latest novelties coming from India. Last but not least, there was the usually very explicit definition of Indian as Hindu, which hampered the recognition of modern Urdu literature in the eyes of most modern Indologists. As Javed Majeed has recently pointed out, even G.A. Grierson in his massive Linguistic Survey of India talked of Urdu's "uncertain citizenship" as an Indian language, and as we have seen he excluded Urdu ("exotic literary Urdu") from his discussion of the contemporary "literature of Hindustan" (1889, vii, Majeed 2018).

To this we may add the weight of Orientalism and its bias in favour of Sanskrit and everything Ur, ancient, original - and the increasingly musty reputation that Orientalism acquired in the European literary sphere. Whereas Sanskrit posts multiplied in European Universities, only Paris had, from 1827, a professor of modern Indian languages, Garcin de Tassy himself. Modern Hindi and Urdu (or Hindustani) were taught in the EIC colleges and at Kings College London from the 1860s and 70s (Bengali, Gujarati, Marathi, Hindi and Hindustani), and in Trinity College Dublin from 1881 (Mishka Sinha, personal communication), but unlike Sanskrit they were taught instrumentally. 
One reason why I find this nineteenth-century "present absence" so interesting is because in many ways it resembles our current predicament in the present globalising moment. The publishing market and literary scholarship tell us that world literature is here, available to us at just a click away. But not only does the claim to systematic inclusion turn out to be a hollow one (Morgan 2015), similar "technologies of recognition" produce blindness to what it not immediately "there" or supercilious disregard and misrecognition towards what does not match the tastes of so-called "world readers", marginalise translation and deny the necessary learning of languages and the persistence of multilingualism in the age of "global English".

In the late nineteenth, teachers and modern Indologists like Pincott, Forbes, or Grierson typically knew Indian writers, intellectuals and literary associations and were ideally placed as "intermediaries" to introduce modern literary writing to European readers, though almost without exception they preferred medieval devotional poetry or martial epics. Their attitude to modern writers, we saw, was predominantly paternalistic. The language remained one of "improvement" and progress, not of aesthetic-literary appreciation. In Trübner's American and Oriental Literary Record book lists are often hotch-ptch, genre attribution haphazard, with a good many genres are called "novels", and we get the sense that, were it not for the industrious Orientalists, nothing would be happening. Praise for G.W. Leitner's attempt to establish a "native University" in Lahore with the object "to revive ancient Oriental learning, and to create and encourage vernacular literature, and the introduction of the best European literature into India", says it all (American $\mathcal{E}$ Oriental Literary Record 8, October 1865, 147).

In the American $\mathcal{E}$ Oriental Literary Record book lists, authors are not always named, and only one Indian author, Michael Madhusudan Datta, merited the honour of a boxcase. The example of Garcin de Tassy, indefatigable translator of Hindi and Urdu works and author of the first history of Urdu literature in any language, who sitting in Paris and without ever going to India compiled annual reports of literature in Urdu and Hindi, highlighting the latest publications and underlining their "literary interest", shows that to "see" contemporary Indian literature was possible - but why weren't there more people like him? 


\section{References}

American \& Oriental Literary Record. 1865-1884. London: Trübner \& Co.

Court, Henry. 1889. The Nașr-i-Benaz̄ir or the Incomparable Prose of Mīr Hasan, literally translated into English. Calcutta: Baptist Mission Press, $2^{\text {nd }}$ ed.

Das, Sisir Kumar. Sahibs and Munshis: an Account of the College of Fort William. New Delhi: Orion Publications, 1978.

Fabian, Johannes. 1983. Time and the other: How anthropology makes its object. New York: Columbia University Press.

Faruqi, Shamsur Rahman. 2001. Early Urdu Literary Culture and History. New Delhi: Oxford University Press.

Foucault, Michel. 1980. "Two Lectures". Power/knowledge: Selected interviews and other writings, 1972-1977. Tr. by Colin Gordon. Harlow: Longman, 78-108.

Garcin de Tassy, Joseph Joseph-Héliodore-Sagesse-Vertu. 1874. La langue et la littérature hindoustanies de 1850-1869: discours d'ouverture du cours d'hindoustani. Paris : Librairie orientale de Maisonneuve et Cie.

Howsam, Leslie. 2014-16. “Trübner”. Oxford Dictionary of National Biography, (c) Oxford University Press 2004-16 All rights reserved.

Knapczyk, Peter A. "Crafting the Cosmopolitan Elegy in North India: Poets, Patrons, and the Urdu Mars iyah, 1707-1857." PhD dissertation, University of Texas at Austin, 2014.

Italia, Maddalena. 2018. “The Erotic Untranslatable: The Modern Reception of Sanskrit Love Poetry in the West and in India". PhD dissertation, SOAS, University of London.

Majeed, Javed. 2019. Nation and Region in Grierson's Linguistic Survey of India. New Delhi: Routledge.

McGregor, R.S. 1972. "Bengal and the Development of Hindi, 1850-80". South Asian Review 5 (2): 137-146.

Morgan, Ann. 2015. Reading the World: Confessions of a literary explorer. London: Harvill Secker.

Mufti, Aamir R. Forget English!: Orientalisms and World Literature. Cambridge, Mass.: Harvard University Press, 2016. 
Mukherjee, Meenakshi. Realism and Reality: the novel and society in India. New Delhi: Oxford University Press.

Pritchett, Frances. n.d. Selected Publications of Fort William College, Calcutta. http://www.columbia.edu/itc/mealac/pritchett/00urdu/baghobahar/BBFORTW $\underline{\text { M.pdf }}$

Safadi, Alison. 2012. "The colonial construction of Hindustani 1800-1947." PhD dissertation, Goldsmiths, University of London.

https://research.gold.ac.uk/8026/1/History_thesis_Safadi.pdf

Shih, Shu-Mei. 2004 "Global Literature and the Technologies of Recognition." PMLA, 119 (1), 16-30. URL: http:/ / www.jstor.org/stable/1261482

Stark, Ulrike. 2007. An empire of books. New Delhi: Permanent Black.

Steadman-Jones, Richard. 2007. Colonialism and Grammatical Representation: John Gilchrist and the Analysis of the Hindustani Language in the Late Eighteenth and Early Nineteenth Centuries. Oxford: Wiley-Blackwell.

Suvorova, Anna. 2000. Masnavi: A study of Urdu romance. Karachi: Oxford University Press.

Trübner, Nicholas. 1865. 'Publisher's Notice'. American \& Oriental Literary Record 1 (March): 1.

Vanita, Ruth. 2012. Gender, Sex, and the City: Urdu Rekhti poetry in India, 1780-1870. Hyderabad: Orient Balckswan.

\section{Figures:}

Fig. 1 Collage of Section titles from Trübner's American $\mathcal{E}$ Oriental Literary Record.

Fig. 2 First page of American \& Oriental Literary Record, March 1865, 1. Courtesy, British Library.

Fig. 3 Title page of The Prem Ságar; or, The Ocean of Love... by Lallú Lál, Late Bhákhá Múnshí of the College of Fort William. A new edition with a vocabulary by Edward B. Eastwick, M.R.A.S., Hertford: printed for the Hon. East-India Company by Stephen Austin, Bookseller, etc., to the East India College, 1851. Author's own copy and photograph.

Fig. 4 Major H. Court, Preface to The Nașr-i-Benaz̦ir or the Incomparable Prose of Mìr Hasan, literally translated into English. Calcutta: Baptist Mission Press, 1889, $2^{\text {nd }}$ ed. 
Fig. 5: "Works of the Bengali Poet, M. Madhusudan Datta, in the Bengali Language", Trübner's American \& Oriental Literary Record, 31 May 1866, 280. Courtesy of the British Library.

Fig. 6. Urdu works by Mirza Ghalib, Nasikh, Amanat, Ali Beg Surur, Muhammad Bakhsh. American \& Oriental Literary Record, April 1869, 434. Courtesy of the British Library.

Fig. 7 Sanskrit books, Trübner's American E Oriental Literary Record, January 1965, 73. Courtesy of the British Library.

Fig. 8. "Harishchandra”, in G.A. Grierson's Modern Vernacular Literature of Hindustan, 1889, 124.

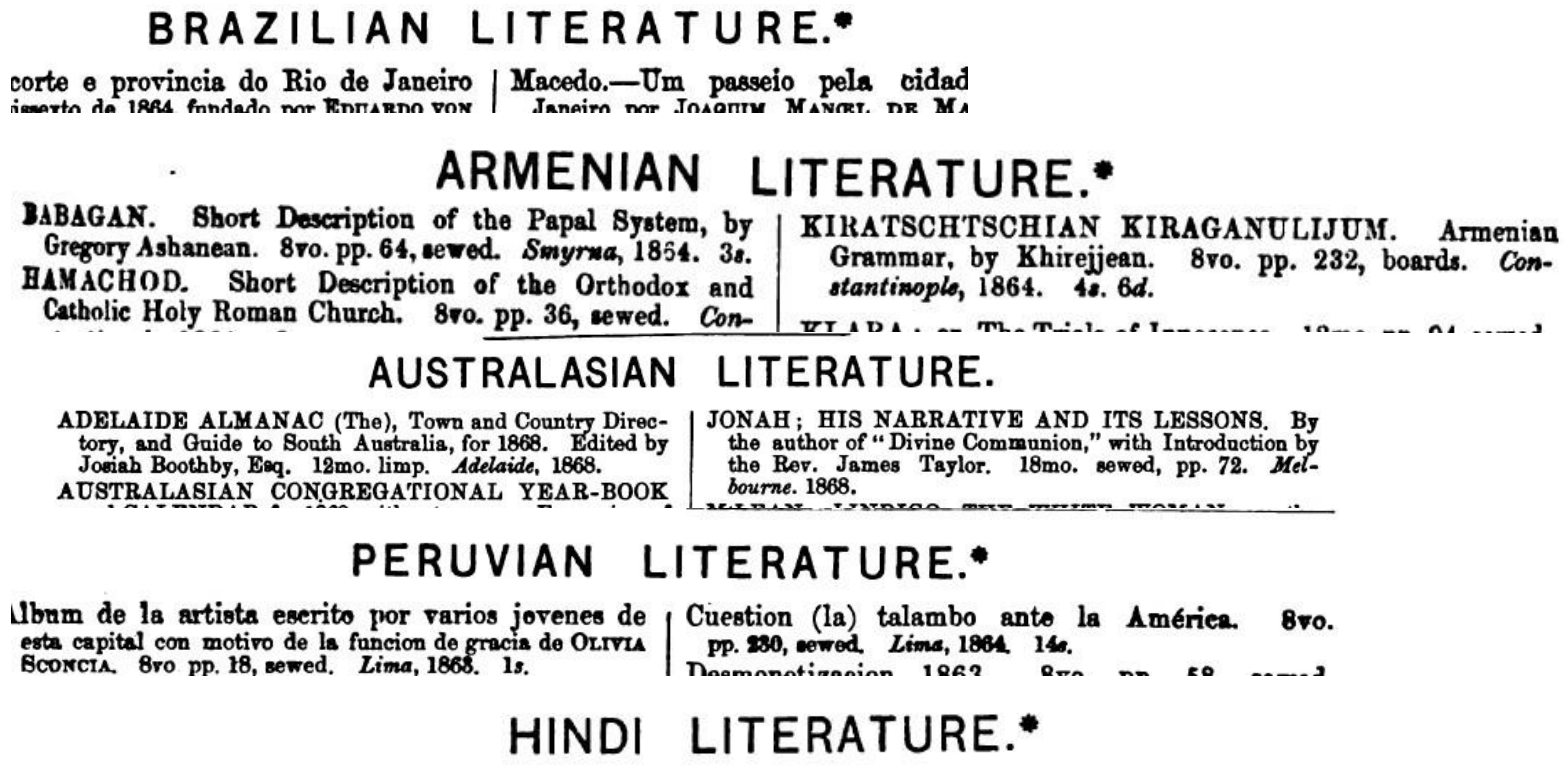

\section{PERUVIAN LITERATURE.*}

Ubum de la artista eserito por varios jovenes de fuestion (la) talambo anto la Amériea. 8vo.

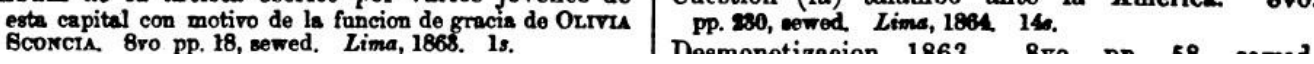

\section{HINDI LITERATURE.*}

BAIYATRA. A work on the Holy Placcs near Braj. PCSTAK GRAHANONKI. On Eclipses. Sanskrit and Lithog. 8vo. pp. 80. Agra. 1s. $6 d$.

\section{MAHRATHI LITERATURE.*}

A Bhimanyocha vivaHA. Lithog. 26 leaves. Bom-| MarUtistotra. Lithog. 14 leaves. Bombay. Bd.

\section{GUJARATI LITERATURE.*}

ABHIMAN-AKITYANA. 8ro. sewed. Bombay. 1s. $6 d$. | LIPIDARS. 8vo. sewed. Bombay. $1 s$.

\section{HINDUSTANI LITERATURE.*}

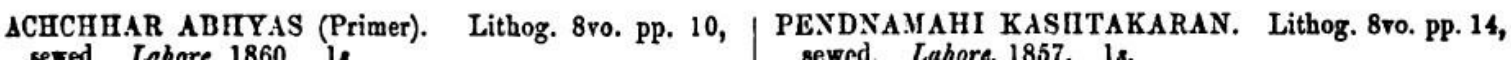

Fig. 1 Collage of Section titles from Trübner's American $\mathcal{E}$ Oriental Literary Record. 


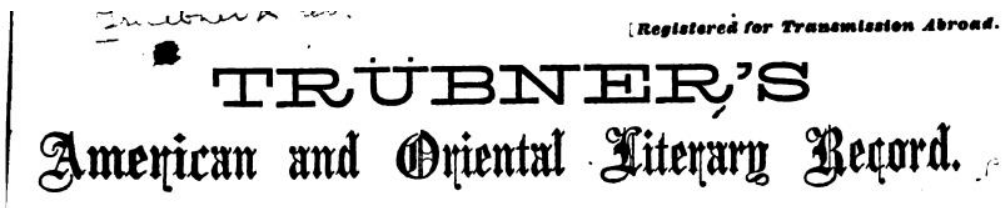

\section{A MONTHLY REGISTER}

of the most important Works published in NORTH and SOUTH AMERICA, in INDIA, CHINA, and the British Colonies: with occasional Notes on German, Dutch, Danish, French, Italian, Spanish, Portuguese, and Russian Books.

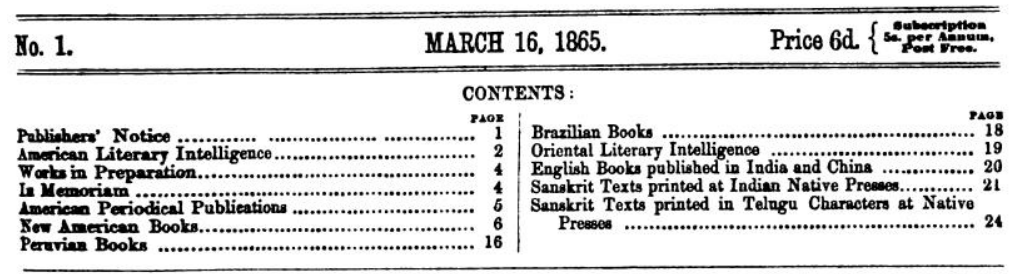

Messrs. TRÜBNER \& Co., 60, Paternoster Row, London, have imported and supply the whole of the American, Peruvian, Brazilian, and Oriental Works named in this Literary Record.

\section{PUBLISHERS' NOTICE.}

Wa desire to bring the literature of the East and West more fully before the reading public of England and Europe; with this view we purpose presenting to our readers a monthly record of every important work published in North and South America, in India, China, and throughout the East. We are not aware work published in North and South America, in India, China, and throughout the East. We are nut aware
of any previous aystematic attempt of this kind, but we think the time is ripe for sach an undertaking, and
wo unhesitatingly ask the support of all students and lovers of literature, believing that when our object is firly understood we shall neither lack readers nor sympathiser

are In the United States of America a large number of really valuable works written in our own language are yearly issuing from the press, selling there by hundreds and thousands, but hardly known bere, simply public. We shall in our monthly is what brief comments may be necessary to show the qualifications of the authors and the nature of their labours. We also purpose occasionally grouping together the books recently published on givan subjects,
so that the student in any department of science and literature may be made acquainted with the best and
most recent American literature on his special branch of study. most recent American literature on his special branch of stady.
The literature of Mexico and of the Republics and States of Central and South America has never yet been brought aystematically before scholars and students; we have the pleasure of presenting in this number two interestiog lists-one of Peruvian, the other of Brazilian books; the former presents a complete summary of the literature (excluding periodicals) published in Peru in the years 1863 and 1864 . We hope in early nambers of our pulication to lay before our readers some details of the literature of Mexico, Guatemala,
Chili, the River Plate States, Venezuela, New Granada and Caba, and to continue giving a regular chronicle books that are insued in these states.

In Indis and China an important English literature is gradually springing up. Of this department we now give a specimen, and in our future numbers we shall give fuller details. Sanskrit literature as well as
books in all the vernacular languages of India and of the East in general will be fully reported upon from time to time. Having opened ap correspondence with native and European scholars in every part of Iudia and in varions parts of China, we hope to render this department of very great interest to all whose studies are in that direction.

From other fields of literature we shall also supply information of interest to readers of all classea. Another feature in our undertaking will be to present copious notes on the bibliography of North and Wo trust our readers will bear in niud that our paf many years, are now in our hands.

Contain in the our readers will bear in miud that our pages are nut of nere ephemeral interest. They will ope will be considered of sufficient importance to rank on the library shelves with the very many valuable bitlographies this century has produced.

Fig. 2 First page of American \& Oriental Literary Record, March 1865, 1. Courtesy, British Library. 


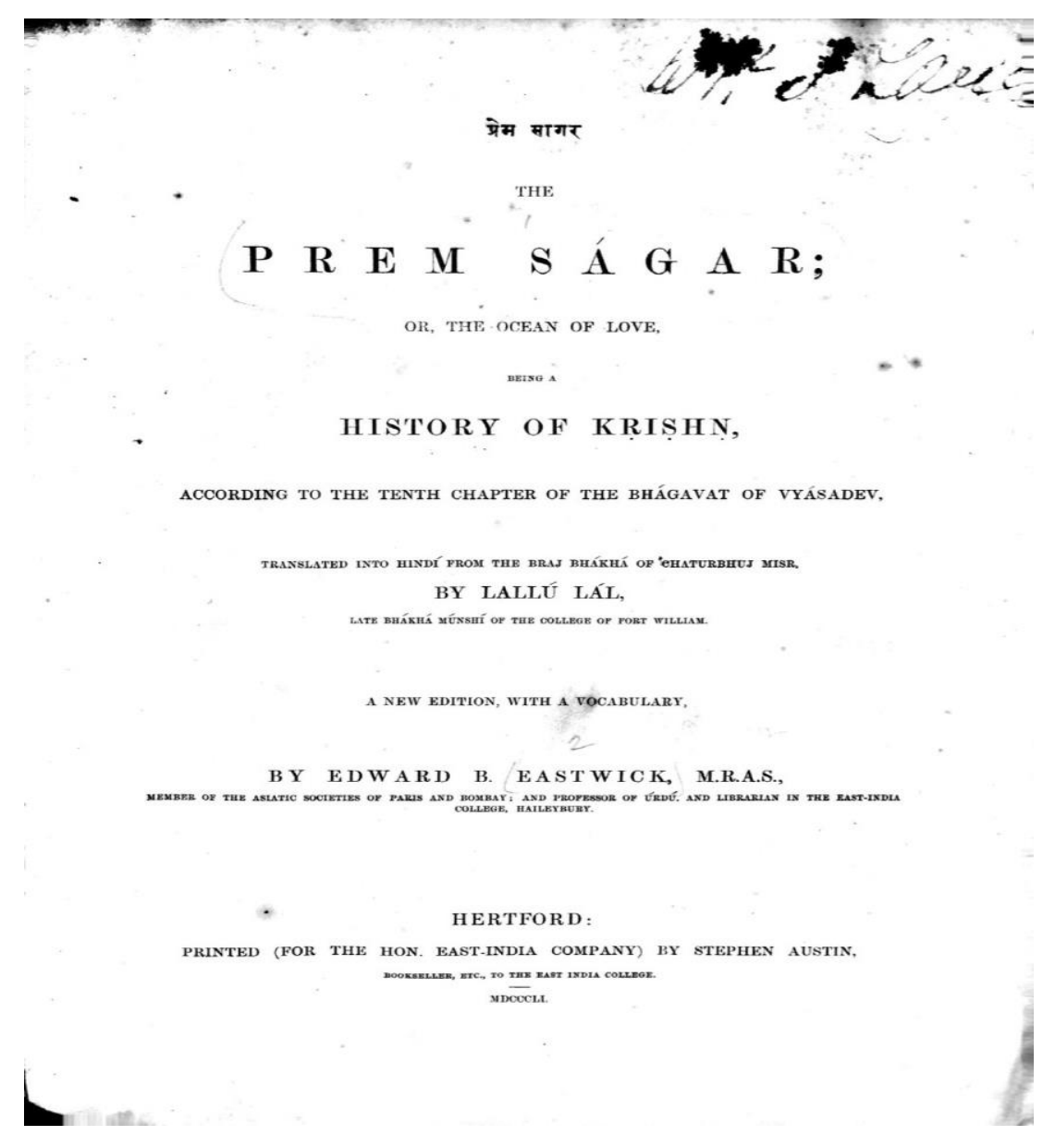

Fig. 3 Title page of The Prem Ságar; or, The Ocean of Love... by Lallú Lál, Late Bhákhá Múnshí of the College of Fort William. A new edition with a vocabulary by Edward B. Eastwick, M.R.A.S., Hertford: printed for the Hon. East-India Company by Stephen Austin, Bookseller, etc., to the East India College, 1851. Author's own copy and photograph. 
THE Nasr-i-Benazir, the second of the three Urda High Proficiency Text Books, which I have undertaken to translate, is a fairy tale, and an excellent specimen of an Eastern novel. The various ceremonies, in usage at Oriental Courts, are most fully deseribed, and the whole book is admirably adapted to give an English student a thorough insight into Bastern customs, modes of speech, and etiquette. Here and there, in the original, there are passages which I have omitted as objectionable, marking them with asterisks, and for the same reason there are a few words which $I$ have not translated literally, but on the whole I have been obliged to make but few alterations. In the poetical parts I have followed the same rule as in my first book, the Araish-i-Mahfil, viz. translating them literally into prose, and keeping the words of each line separate; the notes too, as in the former work, are principally meant for students in England, and words, not in the original, are put within round brackets. There are many sentences which students will find exceeding. ly difficult to understand, but I trust that my translation will prove of assistance to them, as I have endeavoured to render such passages as clearly as possible, after consulting many educated and intelligent natives on the subject.

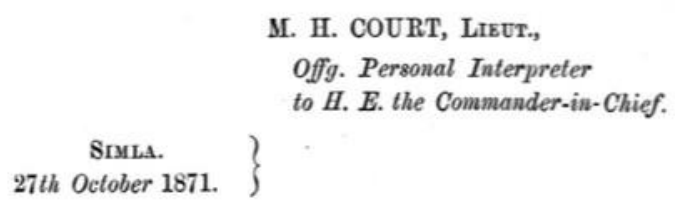

Fig. 4 Major H. Court, Preface to The Nașr-i-Benazīr or the Incomparable Prose of Mīr

Hasan, literally translated into English. Calcutta: Baptist Mission Press, 1889, $2^{\text {nd }}$ ed.

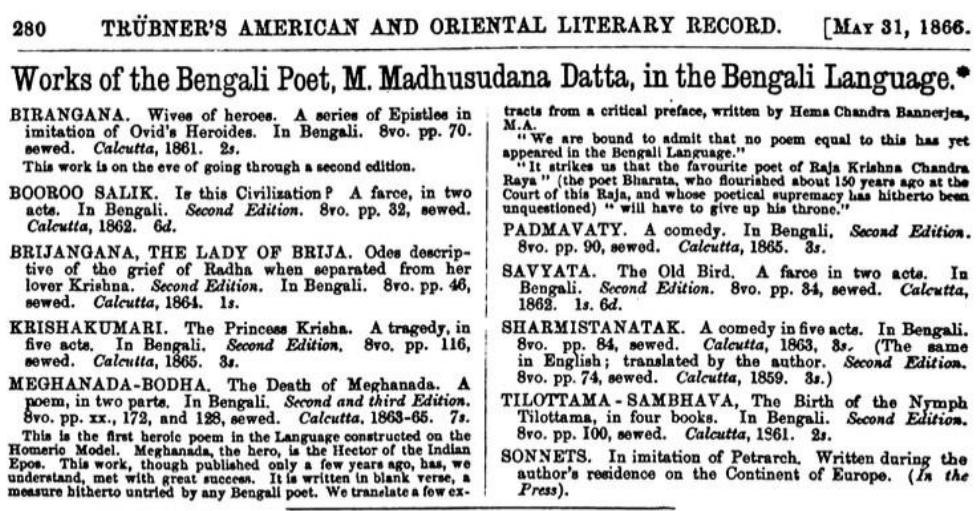

Fig. 5: "Works of the Bengali Poet, M. Madhusudan Datta, in the Bengali Language", Trübner's American \& Oriental Literary Record, 31 May 1866, 280. 


\section{SANSKRIT LITERATURE.*}

BACON. - An explanatory version of Lord Bacon's Nornm Organum. Prepared in Sanskrit by. PaNdit Vitrinala Sagtay, and in English by JayeB R. BALLANTYNB, LL.D. Five parts, 8vo. pp. 320, sewed. Benares, 1852-54. 15s. DATTAKAMIMAMSA and DATTAKACHANDRIKA, with Banskrit Commentaries, and Abstracts in Bergali. In Bengali characters. By Braratachandra Stromani. 8ro. pp. 178, sewed. Caleutta, 1857. 7s. $6 d$.

GITA-GOVINDA. Sanskrit, with a Bengali Commentary. By Yadunath Nrayapanchanan. 8vo. pp. 136, sewed. Calewtla, 1861.68.

HITOPADESA. Sanskrit and Bengali. The translation by Raygopat TARKalankas. 8vo. pp. 330, boards. Calewtta, 1863. 108 .

KADAMBARI. By BANABHATTA. A prose composition in poetical language. Second Edition, 8vo. pp. 412, sewed. Calcucta, 1862. 21 .

KAVIKALPADRUMA. A Repository of Sanskrit Roots rith their meanings in Bengali. By CHANDraxoHax Bidphantabagrsy. 8vo. pp. 166 . Calcutta, 1860. 7s.6d. RAVYA-KALAPA. Edited by Haridas Hirachand. No. I. Containing a Sanskrit Anthology being a collection of the best 37 smaller Poems in the Sanskrit language (some of these hitherto unpublished). 8vo. pp. 146, boards Bombay, 1864. 68.
KAVYA-KALAPA. No. II. Lskshmisahasra Stotra (a poem in veneration of the Goddess Lakshmi) by VRKraTADHVARI ACHARY, author of Vishvagunudarsha and Hastigirichampu. (Hitherto unpublished). Oblong 8vo. pp. 112, boards. Bombay, 1864. 68.

KAVYA-KALAPA. No. III. Vidagdha mukha mandana or the ornament of the mouth of learned, with Notes and Explanations in Sanskrit, by DHurmadass, one of the Jain followers. (Hitherto unpublished). 8vo. pp. 78, boards. Bombay, 1865. 6s.

KAVYA-SANGRAHA. A Sanserit Anthology, being a collection of the best smaller poems in the Sanscrit language. By Dr. John HABBzkLin. 8vo. pp. 532, cloth, Calcutta, 1847. 24s.

MEGHADUTA. Sanscrit and Bengali. The Bengali version in metrical by Bhavanachandra Batax. 8vo. pp. 128, sewed. Calcutta, 1861. 3s.

MITAKSHARA, The. A Compendium of Hindu Law, by Vissaneswara. Founded on the texts of Yajnawalkya. The Vyarahara section, or Jurisprudence. Edited by $\mathbf{S R T}$ laxbmimi Narayaka Nixayalancara, and published under the authority of the Committee of Public Instruction. 8vo. pp. 396, boards. Calcutta, 1829. 21 s.

PRABODHACHANDRODAYA. A Drama. Sanskrit and Bengali. 8vo. pp. 158, cloth. Caleutta, 1861. 68.

- All thase Angho-Indion and Sanskrit Books oan bo supplied by Trubner and Co. Any Oriontal Bosks not Fig. 6 Sanskrit books, Trübner's American \& Oriental Literary Record, January 1965, 73.

581. हृरिग्रुन्र्र, Bābū Harishchandr', of Banāras. Born 9th September 1850.

Sun. The most celebrated of the native poets of the present day. He has done more for the popularisation of vernacular literature than almost any living Indian. He himself was a prolific author in many styles, and he excelled in all. He conducted for many years an excellent vernacular magazine entitled the Harishchandrika. He was son of Gōpāl Chandr' Sähă alias Giri Dhar Banār'si (No. 580), who was a prolific author, but who died at the early age of 27 , in the year 1859 , leaving Harishchandra an orphan only 9 years old. The boy was educated at Queen's College, Banāras, and commenced to write at an early age. In the year 1880 , so greatly had his fame extended that he was given the title of Bhäratēndu, or Moon of India, by the unanimous consent of all the editors of the vernacular papers of India. He died in the year 1885 , universally regretted, being by general con. sent one who was 'ajäta-çatru.' He is best known (see also No. 706) for the Sundart Tilak (quoted in this work as 'Sun.'), published in 1869 (Sam. 1926), which is an anthology of poems in the Sawäya metre from the works of 69 poets. This work is by some said to

Fig. 7. "Harishchandra”, in G.A. Grierson's Modern Vernacular Literature of Hindustan, $1889,124$. 
رائ Râmâyana nazm Urdu. An Imitation of Tulsi Das's Hindi version of the Râmâyana, in Urdu verse, by Shankar Mayâl Farhat. 8vo. pp. 6, (Index), 158, with numerous illustrations, sewed. Lukhnow, A.H. 1282, (1866). 10s.6d.

ديوأب Dînân Hushum. The Dîwân of Hari Shankar Parshâd called Hushum. 8ro. pp. 38, sewed. Benares (no date). $2 s$.

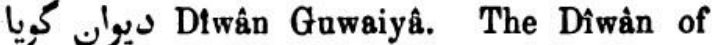
Muhammad Kbân, surnamed Guwaiya, in Urdu. 8vo. pp. 228, sewed. Cawmpore, A.H. 1273 (1856). 78.

ديواب فائin Ghâlib. The Dîwân of Asd Allab Khân Ghâlib, in Urdu. 8vo. pp. 104, sewed. Carnpore, A. H. 1278 (1863). 4 s.

باغ باغ بار منظوم i Bahâr, “The Garden of Spring," - a Poom in Urdu, by Amîr i Allâh, surnained Názim. Royal 8vo. pp. 83, with four columns each, sewed. Lukhnow, A. н. 1273 (1856). 3s. 6d.

Bahâristân i Sukhun, by Nâsiḥ Âtish Âbâd. Three sets of Odes, in Urdu, each turning on one of the names of the poet. 8ro. pp. 230, sewed. Lukhnoro, (no date). 98.

عرض حاجات فقير i tâajât i Faḳír. Poems by Muhammad Huşain Faḳir, in Urdu. Rojal 8vo. pp. 24, double columns, sewed. Lukhnow, A. в. 1273 (1856). $2 s$.

Indra Sabhâ. A Poem, by Amânat

Fasíh Zabân, in Urdu. 8vo. pp. 30, sewed. Gorukpore,

A.B.. 1282 (1866). 18. $6 d$.

Fig. 8 Urdu works by Mirza Ghalib, Nasikh, Amanat, Ali Beg Surur, Muhammad Bakhsh. American E Oriental Literary Record, April 1869, 434. Courtesy of the British Library.

\section{BRAZILIAN LITERATURE.*}

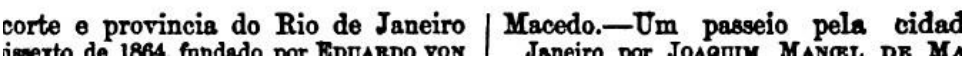

\section{ARMENIAN LITERATURE.*}

BABAGAN. Short Description of the Papal System, by Gregory Ashanean. 870. pp. 64, wewed. Smyrwa, 1854. 3s. BAMACHOD. Short Description of the Orthodox and Catholic Holy Roman Church. 8ro. pp. 36, sewed. Con-

KIRATSCHTSCHIAN KIRAGANULIJUM. Armenian Grammar, by Khirejjean. 8vo. pp. 232, boards. Constantinople, 1864. 4s. 6d.

\section{AUSTRALASIAN LITERATURE.}

ADELAIDE ALMANAC (The), Town and Country Direc- JONAH; HIS NARRATIVE AND ITS LESSONS. By tory, and Guide to South Australis, for 1868. Edited by the anthor of " Divine Communion," with Introduction by Joviah Boothby, Eeq. 12mo. limp. Adelaide, 1868. AUSTRALASIAN CONGREGATIONAL YEAR-BOOK Bourne. 1868 .

\section{PERUVIAN LITERATURE.*}

Ubum de la artista eserito por varios jovenes de Cuestion (la) talambo anto la Amérier. 8vo. esta capital con motivo de la funcion de gracia de Os.rvu Scovcil. 8 ro pp. 18, sewed. Lima, 1868. 1s. pp. 280, newed. Lima, 1861 14. HINDI LITERATURE.*

BATYATRA. A work on the Holy Placcs near Braj. PCSTAK GRAHANONKI. On Eclipses. Sanskrit and lithoz. 8vo. pp. 80 . Agra. 1s. $6 d$. Persian. Lithog. 8vo. Agra. 18.6d.

\section{MAHRATHI LITERATURE.*}

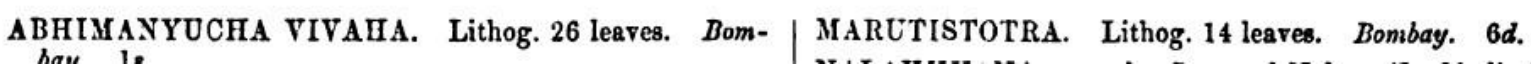




\section{GUJARATI LITERATURE.*}

ABHIMAN-AKITYANA. 8ro. sewed. Bombay. 1s.6d. | LIPIDARS. 8vo. sewed. Bombay. 1s.

\section{HINDUSTANI LITERATURE.*}

ACHCHHAR ABTYAS (Primer). Lithog. 8vo. Pp, 10, PENDNAMAHI KASITTAKARAN. Lithog. 8vo. Pp. 14, MONGOLIAN AND TIBETAN BOOKS, PUBLISHED AND FOR SALE OPPOSITE THE YUNG-HO-KUNG, AT PEKING.

(Imported by Triibner \& Co., 60, Paternoster Row, London.)

1. Khutuktu sain chak on yage kulghen orosiba. (Great vehicle of the good times.) 2 vols. $266 s$.

2. Tantara (ka). (First Tantra.) This is an ascetic formulsry of meaningless words. It begins with an invocation to the Buddhist trinity, three lines in Sanskrit, the same is repeated, three lines in Tibetan, and the same in Mongol. A similar invocation is found at the beginning of a great many of the Mongol books. $286 s$.

3. Tantara (za). (Twenty-second Tantra.) This is
11. In yin talai yin darolka dzaba tak dsing nghem on talai ban nghen on domil $\mathrm{i}$ tatain kol on oilatin dai ohagan aran kemekr orosibai. (Titlo in Tibetan : Minggi djamaté hidjabs ganons dega yiga tohene po okada gri djamató ham akada ragas gosal byeda nam tohena po jeo bys baba jugas oo.) (Ocean of Names, etc.) A Tibeten
Mongol Dictionary. See Preface to Schmidt's Tibetan Dictionary.) 3 vols, \&2 2 s.

12. Bamtsa raksa kemeku tabun sakiyan naradu orosiba. (The domon Bamen's five prevervatives.) 